\title{
Correction to: Lacan Noir: Lacan and Afro-pessimism
}

\section{Correction to:}

\section{S. Marriott, Lacan Noir, The Palgrave Lacan Series, https://doi.org/10.1007/978-3-030-74978-1}

The following corrections have been incorporated into the publication. Page 2, line 13 - " $\mathrm{S}$ " in parenthesis has been corrected to " $\mathrm{s}$ ", and it should read "a pure exteriority in meaning (s)."

Page 17, line 5 - "Difference. Division." has been added at the beginning of the sentence.

Page 64, line 27 - "Mauvais Genie" has been added at the beginning of the sentence.

Page 136, line 6 - the word "not" has been inserted after the word "is". It should read "is not an ontological essence".

Additionally, some typographical errors have been corrected.

The updated online version of the chapters can be found at https://doi.org/10.1007/978-3-030-74978-1_1 https://doi.org/10.1007/978-3-030-74978-1_2 https://doi.org/10.1007/978-3-030-74978-1_3

(C) The Author(s), under exclusive license to Springer Nature Switzerland AG 2022 